\title{
REKETTYE Gábor A HATALMI ÁTALAKULÁS GLOBÁLIS MEGATRENDJE ÉS A NEMZETKÖZI MARKETING
}

A nemzetközi marketing múvelése a világgazdasági változások következtében gyors növekedésben van, és ebből következően jelentősége az elméletben, a kutatásban és az oktatásban is egyre nô. A tanulmány a nemzetközi kereskedelem jelenlegi és várható adatainak felhasználásával bizonyítja ezt a trendet. A nemzetközi kereskedelem, gyorsabban nô, mint a GDP elóálítása, ehhez társul még az a tény, hogy egyre bővülnek az árumozgással nem járó piacralépési módok, amelyek szintén a nemzetközi marketing gyakorlatát teszik egyre fontosabbá. A nemzetközi marketing kulturális oldala kiemelt jelentőségre tesz majd szert. Ennek bizonyítására a tanulmány a hatalmi átalakulás globális megatrendjét elemzi. A gazdasági hatalom gyors ütemben vándorol a világgazdaságot eddig meghatározó régiókból keletre, elsôsorban Kínába és Indiába. A magasabb gazdasági növekedés következtében ezen ország lakosságának egyre nagyobb hányada kerül a középosztályba és jelent egyre nagyobb piacokat az ottani és a nyugati vállalatok számára. Ezen növekvó piacok megdolgozása kulturális érzékenységet, a nemzetközi marketing egyre kifinomultabb eszközeinek alkalmazását követeli.

Kulcsszavak: nemzetközi marketing, hatalmi átalakulás, kulturális érzékenyég, keleti piacok

Ha abból a tényből indulunk ki, hogy nem a marketing mozgatja a világot, hanem a világ - beleértve a gazdaságot és a társadalmat - folyamatosan változik (reményeink szerint fejlődik), a marketing pedig a maga eszközeivel ehhez a változáshoz igazodik, alkalmazkodik, akkor arra kérdésre, hogy milyen trendek fognak a jövőben érződni a marketingben, csak akkor tudunk választ adni, ha először számba vesszük a világban végbemenő globális változásokat.

Ez a feladat azonban egyáltalán nem könnyú, és messze meghaladja egy-egy kutató kompetenciáját. A jövőkutatással nemzetközi szervezetek intézetei foglalkoznak jól képzett szakemberek tömegével és olyan számítástechnikai kapacitásokkal, amelyek alkalmasak arra, hogy elemezzék a múlt és a jelen adatait, az adatok milliárdjai alapján modelleket alkossanak, amelyek azután lehetôvé teszik azt, hogy a jövő alakulásának lehetséges szcenárióit felvázolják és ütköztessék.

Tovább nehezíti az elôrejelzéseket az a körülmény, hogy civilizációnk történetében a XXI. század első tizenöt éve nagyon változatos, hektikus, vagy ha Kotler egyik könyvének címszavával élünk, 'kaotikus' volt. A bizonytalan kiindulás bizonytalan eredményeket szül. Ez oka lehet annak, hogy az imént említett nemzetközi kutatóintézetek prognózisai is jelentősen eltérnek egymástól, sok-sok vitára adva lehetôséget.

Nagyon nagy merészség tehát részemról az, hogy elvállaltam egy ilyen jellegú tanulmány elkészítését. Ami mégis erre ösztönzött, az annak a kis - Hetesi Erzsébettel és ifj. Rekettye Gáborral együtt háromfós - önkéntesen összeállt kutatócsoportnak az eddigi eredményei voltak, amely csoport 2008 óta múködik együtt ebben a témában. A kutatói csoport eredményeit hazai és nemzetközi konferenciákon, illetve hazai és nemzetközi folyóiratokban publikálta (Rekettye - ifj. Rekettye, 2009; Hetesi, 2009; Rekettye - Hetesi, 2010). A nemzetközi szakirodalom részletes tanulmányozása után hat olyan megatrendet azonosítottunk, amelyek meghatározó jelentőséggel lesznek a globális üzleti és marketingkörnyezetre. Ezek a következők (Rekettye - Rekettye jr., 2013):

1. a világgazdaságban végbemenő radikális átrendeződés, azaz a gazdasági hatalom nyugatról keletre és délre tolódása,

2. a globális klímaváltozás (felmelegedés),

3. a demográfiai trendek alakulása (öregedés a nyugati társadalmakban, túlnépesedés és urbanizáció a fejlődő világban),

4. a technológia (főleg az ICT-szektor) területén végbemenő gyorsuló fejlődés,

5. a gazdasági válság utóhatásai (a fogyasztói szokások radikális átalakulása),

6. a proliferáció, amely egyre több kommunikációs eszköz és egyre nagyobb márkadömpingben jelenik meg. 
A tanulmány terjedelme nem teszi lehetôvé mindezen trendek részletes bemutatását. Éppen ezért úgy gondolom, hogy jelen dolgozat célját jól szolgálja az, ha az itt felsoroltak közül egyet kiemelek, és annak a marketingre gyakorolt hatását vizsgálom részletesebben.

A kiemelt változás, nevezhetjük megatrendnek is: a világgazdaságban végbemenó hatalmi átrendezódés, aminek egyik komoly hatása, hogy a marketing az elkövetkező évtizedekben egyre inkább nemzetközivé válik. A következőkben tehát azt szeretném bizonyítani, hogy a nemzetközi marketing egyre fontosabbá válik mind a gyakorlatban, mind az oktatásban és kutatásban.

A tanulmányban először a fogalmakat tekintjük át, majd a nemzetköziesedés jelenlegi helyzetét elemezzük, és csak ezt követően próbáljuk meg a jövőbeni trendeket bemutatni.

\section{A nemzetközi marketing fogalma és fokozatai, a nemzetközi marketinget folytató vállalatok típusai}

A nemzetközi marketinget úgy lehet megfogalmazni, hogy azt elkülönítjük a belföldi marketingtől. Eszerint minden olyan marketingtevékenység nemzetközi marketingtevékenységnek számit, ami külföldön folyik, külföldre irányul vagy figyelembe vesz külföldi igényeket és változásokat (Rekettye et al., 2015, p. 35.). Czinkota és Ronkainen $(2004$, p. 4.) a marketing alapkategóriáiból kiindulva fogalmazzák meg definícióját. Szerintük: „A nemzetközi marketing olyan folyamat, amelynek során nemzeti határokon túlnyúló tranzakciókat tervezünk és folytatunk azért, hogy olyan cseréket hozzunk létre, amelyek kielégítik az egyének és szervezetek céljait." Hozzáfüzik még, hogy a nemzetközi marketing olyan tevékenység, amit gyakran nagyon agresszíven kell folytatni, és azok, akik nem vesznek részt ilyen tranzakciókban, szintén ki vannak téve e tranzakciók hatásainak.

Több szerző különválasztja a nemzetközi marketinget multinacionális és globális marketingre. Az első közelítés az országonkénti különbségekre, a második az azonosságokra koncentrál. Mühlbacher, Dahringer és Leihs (2006) a különbségeket elismerve a második megközelítést tartják sikeresebbnek.

Keegan és Green (2013, p. 28.) szerint - akik könyvüknek is a Global marketing címet adták - a szokásos és a globális marketing közötti alapvetố különbség a tevékenység területi különbségében van. „A globális marketinget folytató vállalat fontos üzleti tevékenységeket végez saját országának határain kívül" - írják.

A nemzetközi vállalatokkal foglalkozó szakirodalom megkülönböztet hazai vállalatot, nemzetközi vállalatot más néven multinacionális vállalatot és transznacionális vállalatot. A közgazdasági lexikonok (lásd pl. http://www.businessdictionary.com definícióját) szerint az a vállalat, amely bevételének több, mint egynegyedét külföldi tevékenységekból produkálja, már a multinacionális vállalatok közé tartozik. A magyar közfelfogás szerint a „multik” fogalma a nagy nemzetközi vállalatokhoz kötődik, holott „,a világ több, mint 60.000 multinacionális vállalatának nagy része kisvagy középvállalat" (Czakó - Reszegi, 2010, p. 34.). Megjegyzendo, hogy Czakó és Reszegi adatai mára már sokat változtak. Az UNCTAD 2013-as jelentése szerint a multinacionális vállalatok száma már 2013ban meghaladta a száztízezret. A három vállalattípust a külföldi érintettség szempontjából a következők szerint lehet meghatározni:

Hazai vállalat az, amelyik legfontosabb gazdasági múveleteit saját országának határain belül végzi.

Multinacionális vállalat az, amelyik több országban folytat különböző múveleteket, de főhadiszállása egyértelmúen egy országhoz, a hazaihoz kötődik.

Transznacionális vállalat, amelyik több országban múködik és rendelkezik komoly gazdasági erôforrásokkal, de egyetlen országot sem tekint hazainak.

Megjegyzendő, hogy a multinacionális és a transznacionális vállalat fogalmát még a nagy nemzetközi szervezetek szintjén is keverik. Így pl. WTO (a Világkereskedelemi Szervezet) 2014. évi jelentésében multinacionális vállalatokról ír, addig az UNCTAD 2014. évi jelentése TNC-t (transnational company - transznacionális vállalat) említ.

Nyilvánvaló, hogy a nemzetközi marketing zömét a multinacionális és a transznacionális vállalatok végzik.

\section{A nemzetközi marketing jelenlegi szerepének becslése}

A marketingtevékenységnek nincsenek parametrikus mérőszámai, következésképpen azt megítélni, hogy az összes marketingtevékenységnek mekkora része nemzetközi, lehetetlen. Bizonyos becsléseket azonban megengedhetünk magunknak.

Feltételezhetjük azt, hogy a nemzetközi piacokra kerülő áruk egységéhez közel olyan mértékú marketing társul, mint a hazai piacon termelt és hazai piacon értékesített áruk egységéhez. Ha ezt elfogadjuk, akkor a nemzetközi forgalomba kerüló áruk mennyisége és értéke - azaz a külkereskedelmi forgalom, amelyet statisztikailag mérnek - alapján már tehetünk durva becsléseket.

Nos, a világ külkereskedelmi forgalma meglehetôsen nagy, és növekvőben, a második világháborút követôen, de különösen a XX. század végén és a XXI. század elején különösen gyors növekedésben van. Ez 
a fejlemény összefüggésben van a globalizációval, amelynek eredményeképpen a kereskedelmi korlátok csökkentek, az áruk, a tôke és a munkaerő mozgása szabadabbá vált, javultak az áruszállítás, a közlekedés és a nemzetközi kommunikáció feltételei.

A WTO jelentése szerint az áruexport 2013-ban 18,8 trillió dollár volt, amihez még 4,6 trillió ún. kereskedelmi szolgáltatás is járult (szállítás, pénzügyi szolgáltatás, licencdíjak stb.). Itt kell megjegyezni, hogy a szolgáltatások számbavétele még egyáltalán nem megoldott a nemzetközi statisztikában. A WTO hivatkozott jelentése szerint is a „tradicionális kereskedelmi statisztika, amely az áruk forgalmát bruttó formában - és nem a hozzáadott érték - szintjén méri, nagyon jelentősen alábecsüllheti a szolgáltatások hozzájárulását a külkereskedelmi forgalomhoz" (WTO, 2014, p. 25.).

A külkereskedelmi forgalom nagysága önmagában nem sokat mond, de ha hozzátesszük azt is, hogy ez az érték 2013-ban a világon megtermelt GDP 32\%-ának megfeleló nagyság, akkor már valami elképzelésünk lehet az ehhez kapcsolódó marketing nagyságáról is. Továbbá, ha az elmúlt évtizedek tendenciát nézzük, akkor azt is megállapíthatjuk, hogy a külkereskedelmi forgalom növekedése - jellemzóen - jóval meghaladja a termelés, illetve a GDP előállításának növekedését ( 1 . ábra).

1.ábra

A világ GDP-termelésének, illetve a világkereskedelmi forgalom növekedésének indexei $(1980=100)$

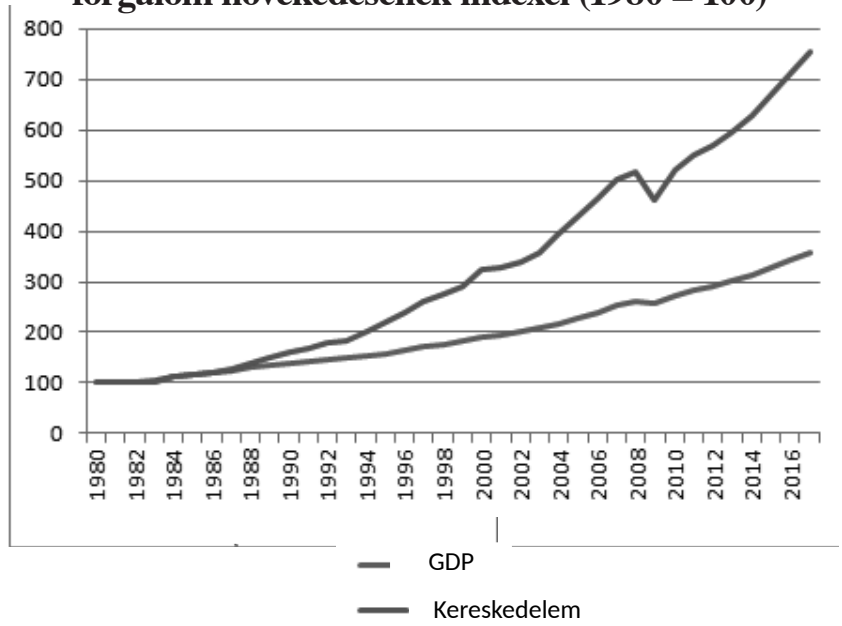

IMF WEO (2012. október)

Ha ezekből az adatokból kiindulva elórejelzést készítünk, akkor arra az eredményre jutunk, hogy külkereskedelmi forgalom egyre nagyobb arány képvisel majd a világon megtermelt GDP-hez viszonyítva. Ez az arány természetesen országonként más és más. Ismert összefüggés, hogy a nagyobb országok esetében az export/GDP arány mindig alacsonyabb, mint a ki- sebb országok esetében. Az 1. táblázat néhány országra vonatkozó adatai igazolják ezt.

1. táblázat

Az export/GDP és az import/GDP arány néhány kiemelt országban $(2013, \%)$

\begin{tabular}{|l|r|r|}
\hline Ország & $\begin{array}{r}\text { Exportérték a } \\
\text { GDP \%-ában }\end{array}$ & $\begin{array}{r}\text { Importérték a } \\
\text { GDP \%-ában }\end{array}$ \\
\hline Hollandia & 82,9 & 72,6 \\
\hline India & 25,2 & 26,3 \\
\hline Japán & 16,2 & 19,0 \\
\hline Kína & 26,4 & 23,8 \\
\hline Magyarország & 88,8 & 81,2 \\
\hline Németország & 45,6 & 39,8 \\
\hline USA & 13,5 & 16,5 \\
\hline
\end{tabular}

IMF (http://data.worldbank.org/indicator/NE.EXP.GNFS.ZS) letöltve: 2015. június 21.

Megjegyzés: Magyarország ezzel az export/GDP aránnyal a hatodik helyen van a világrangsorban és harmadik helyen Európában.

Összességében megállapíthatjuk, hogy a külföldi termékek meglehetősen magas részesedést képviselnek egyes országok piacain. Ez - korábbi feltételezésünkből kiindulva - egyidejúleg azt is jelenti, hogy a nemzetközi marketing ilyen arányban szintén jelen van ezen országok gazdaságában.

Mielőtt még azt a kritikát kapná a jelen feltételezésen alapuló elemzés, hogy túlzottan egyoldalú, tenni kell néhány korrekciót:

a. Kritikaként fogalmazható meg, hogy a nemzetközi kereskedelembe kerülő áruk egy része - energiahordozók, nyersanyagok, alapanyagok - olyan, amely nem igazán igényel intenzív marketingtevékenységet. Igaz, de azt is hozzá kell tenni, hogy már ma is, de a jövőben még inkább érvényesül az a törekvés, hogy a kínálók még a homogén termékeket is a marketing eszközeivel megkülönböztessék - differenciálják.

b. Tovább menve: a nemzetközi kereskedelemnek egy részét - főleg a kelet-nyugati (vagy a korábbi terminológiával ,az észak-déli”) árucserét- ma már sokan a globális ellátási lánc felfelé menő (upstream) szakaszának tekintik. Baldwin (2011) a globális ellátási láncok megjelenését a „termelési csomag" második 'kibontásaként' aposztrofálja. Az első még a XIX. században, az iparosodás korszakában ment végbe, amikor is a termelés földrajzi helye elválasztódott a fogyasztóktól. A globalizáció következtében most végbemenő 'második csomagkibontás' azt jelenti, hogy a termelési folyamat egyes fázisainak sem kell föld- 
rajzilag közel lenniük egymáshoz. A világvállalatok minden termelési fázist oda helyeznek, ahol annak végrehajtásához legjobbak a feltételek. Így a nemzetközi kereskedelem jelentös része a multinacionális vállalatokon belüli kereskedelemmé alakult át. A vállalaton belüli áruk mozgása szintén olyan, ami nem nagy marketingtartalmat igényel. Az ilyen jellegú árumozgás nyomon követése azonban nem egyszerú.

Ha az (a) és (b) pontban leírtakat megpróbáljuk öszszegezni, akkor - nagyon durva becsléssel - azt mondhatjuk, hogy a nemzetközi kereskedelembe kerülő áruknak és szolgáltatásoknak közel fele olyan, amely valójában nem igényel komolyabb marketingtámogatást. Tehát alaptételünket - nevezetesen azt, hogy a nemzetközi marketing jelentősége egyre nagyobb - nem támogatja. Azonban néhány olyan tényezóre is fel kell hívni a figyelmet, amelyek az előzókben vázolt csökkentő tényezőket ellensúlyozzák, sôt hatásukban meg is haladják azokat.

c. Bizonyíthatóan egyre több olyan külföldi marketingakcióval lehet találkozni, amelyekhez nem társul árumozgás. Ha végig tekintünk a külföldi piacok megdolgozásának (a piacra jutásnak) a lehetséges módjain, akkor láthatjuk, hogy ezek egy része külföldi termelést feltételez jellemzően az ottani piac kiszolgálása céljából; és így kevés vagy semennyi nemzetközi árumozgás jellemzi (2.ábra).

2. ábra

\section{Piacra lépés külföldi termeléssel}

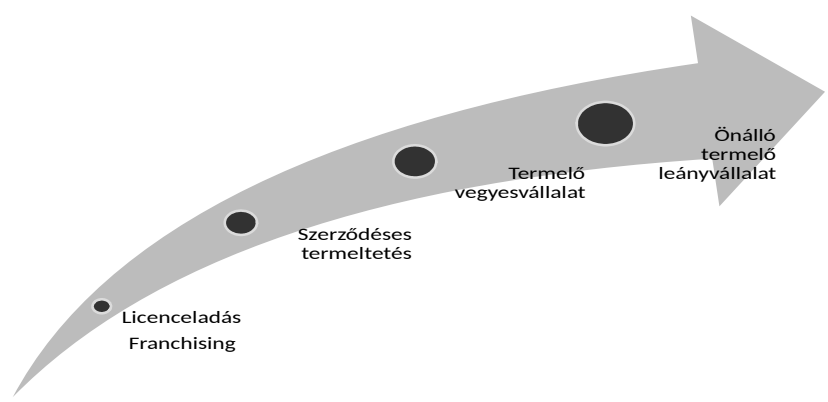

Megjegyzés: A felfelé irányuló nyíl a szükséges tőke nagyságának, a kockázat mértékének és az ellenőrzés lehetőségének növekedését jelképezi.

Gondoljunk csak arra, hogy a McDonalds ott van és marketinget folytat majdnem mindenhol, de árumozgás nincs (vagy csak minimális). Ami a nemzetközi statisztikákban megjelenhet, az a franchise-díj, amely persze töredéke a forgalomnak. De példák tömegét lehetne felhozni a fizikai áruk területéról is: a japán autógyártók legnagyobb piacukat, az USA-t az ott gyártott autókkal látják el. A Suzuki Magyarországon gyártja a magyar piacra szánt modelljét, az Unilever Veszprémben gyártja az Algida jégkrémet. A magyar példák annyiban mások, hogy a magyar piac viszonylag kis mérete miatt az itt termelt termékeket nemcsak Magyarországon forgalmazzák, hanem jelentős részük exportra kerül harmadik országokba. A tanulmány korábbi részében említett magas magyar exportarányban ezek a termelók is benne vannak.

Az önálló termelővállalat létrehozásának alapvetően két módja van: cégek megvásárlása és/vagy összeolvadása (A \& M - acquisitions and mergers) vagy az ún. zöldmezős beruházás révén. Mindkettő az ún. közvetlen külföldi tőkebefektetés (FDI - foreign direct investment) kategóriájába tartozik.

Visszatérve alapgondolatunkhoz, azok a külpiaci múveletek, amelyek nem járnak nemzetközi árumozgással, valójában nem kerülnek be a statisztikákba, ezeknek a nagyságrendjét megbecsülni is kilátástalan vállalkozás. Valamilyen tájékoztatást a FDI-ra vonatkozó nemzetközi adatok nyújthatnak. 2014-ben a fejlődő világba irányuló közvetlen tőkebefektetés értéke történelmi magasságba emelkedett a maga 681 milliárd dolláros összegével. Kína lett a múködő tőke legnagyobb befogadó országa (UNCTAD, 2015). Az UNCTAD jelentése szerint fejlődő világ külföldi múködőtőke-állománya 2014-ben elérte a 25,5 trillió dollárt. Gondoljunk csak bele, mekkora összegről van szó, és - ne feledjük ez múköőô tôke, azaz ebből termelés lett (vagy lesz) és amit termelnek azt megfeleló marketingtámogatással el is akarják adni, és ez a marketingtámogatás kizárólag a nemzetközi marketing keretei közé tartozik. (És ez még akkor is igaz, ha tudjuk, hogy az FDI egy része a kitermelőiparba érkezik.)

d. A nemzetközi marketing jelentőségének megértéséhez egy ágazatot külön is ki kell emelnünk. Ez a kereskedelem. Az importált és hazai gyártású fogyasztási cikkek (és kisebb részben a termelóeszközök) a közvetítókereskedelem útján jutnak el a vevőkhöz. És, ha ez a kereskedő külföldi cég, akkor az ő marketingtevékenysége is a nemzetközi marketinghez tartozik. Mint ismeretes a tömeg-kiskereskedelem területén jelentôs koncentrációnak és egyidejúleg a tömeg-kiskereskedelem nemzetköziesedésének vagyunk tanúi. A világ legnagyobb kereskedelmi vállalkozásai - így a Magyarországon is jelen levők - nemzetköziesedési foka meglehetôsen magas: a Tesco árbevételének 35\%-a, a Metro árbevételének $61 \%$-a, a Lidl árbevételének 56\%-a, az Aldi árbevételének 57\%-a származik külföldrôl (Forrás: https://nrf.com/news/global/global-powers-of-retailing-top-250-highlights-1). 
Összefoglalva a jelenlegi helyzetet megállapíthatjuk, hogy a nemzetközi marketing egyre nagyobb mértékben van jelen a világgazdaságban. Bizonyítottuk ezt

- a nemzetközi kereskedelem magas növekedési ütemével, és a nemzetközi áruforgalomnak a világ GDP termeléséhez viszonyított magas és egyre növekvő arányával,

- a múködő tőke magas arányával és annak gyorsuló növekedésével, valamint

- a kereskedelem globalizálódásával és az egyre koncentrálódó kiskereskedelem fokozódó nemzetköziesedésével.

\section{Egy kitérő: a nemzetközi marketing Magyarországon - az ún. ,mosolygörbe” hatása}

Magyarország nagyon erősen kötődik a nemzetközi gazdasághoz, ebból az következik, hogy a nemzetközi marketingnek itt is kiemelt jelentósége kell, hogy legyen. Ez azonban csak részben van így. Tegyünk itt egy kis kitérőt - a fejlődő országokra veszélyt jelentō, és nálunk is megjelenő - mosolygörbe-hatásról!

A téma összefüggésben van a Baldwin alapján kifejtett ún. második kicsomagolással, azaz azzal, hogy a vállalati ellátási lánc egyes tagjainak nem feltétlenül kell egymás közelében lenniük. Igy a fejlődő országok - és ebből a szempontból tulajdonképpen Magyarország is ide sorolható - ahelyett, hogy felépítenék azt, csatlakozhatnak egy-egy globális ellátási lánchoz. A félelem az, hogy az ellátási lánc ,jó fázisai” a fejlett országokban maradnak, miközben a „rossz munkákat” a fejlődő országok veszik át (Baldwin et al., 2014). Ez a félelem a „mosolygörbe” néven elhíresült intellektuális konstrukcióval van összefüggésben. A mosolygörbét Stan Shih, az Acer cég alapítója alkotta meg még a 90es évek elején (3. ábra).

3. ábra

A mosolygörbe a XXI. században (a görbe nevét a mosolyra emlékeztetó alakjáról kapta) Baldwin et al. (2014, p. 2.) alapján szerkesztve

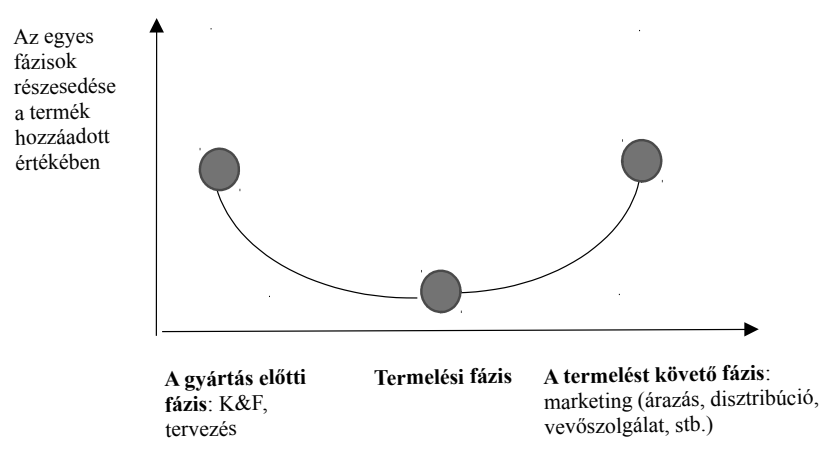

A mosolygörbe azt mutatja be, hogy az ellátási láncon belül a gyártási (termelési) fázis eredményezi a legkisebb hozzáadott értéket, a termelés előtti fázis tevékenységeivel (kutatás-fejlesztés, tervezés, dizájn) és a termelést követő, jellemzően marketingjellegú tevékenységekkel szemben. Nos, a félelem a fejlôdő országok részéról az, hogy a fejlett országok vállalatai megtartják maguknál a nyitó és befejező fázis, és kihelyezik a kisebb hozzáadott értéket képviselő termelési szakaszt.

Nos, ha a magyar részvételt elemezzük a nemzetközi színtéren, akkor nagyon hasonló következtetésekre juthatunk. Az egészen magas magyar kivitel nagyon nagy része az alacsonyabb hozzáadott értékú gyártási, összeszerelési tevékenység kiszállításából áll, míg a magasabb hozzáadott értékú fázisokat más országok vállalatai fölözik le. Vegyük példának a kecskeméti Mercedes-gyártást. A kutatás-fejlesztés, a tervezés Németországban történik, és a késztermékek értékesítését, marketingjét is a cég nem magyarországi részlege végzi. A kiszállított autók természetesen növelik a magyar exportot, de hozzáadott értékből Magyarországon megtermelt rész kisebb. Persze vannak kivételek is: van néhány jó magyar márka, amelynél mindegyik fázis magyar kézben van, és arra is van példa, hogy külföldi cégek magasabb hozzáadott értékú tevékenységeket is kihelyeznek Magyarországra.

Ha ezt így elfogadjuk, akkor megállapítható, hogy magyar export nagy része nem igényel nagy magyar marketing-hozzájárulást. A magyar részról kifejtett nemzetközi marketing szerepe tehát az exportoldalon nem jelentôs.

Annál többet találkozhatunk a nemzetközi marketing megnyilvánulásaival a belföldi piacon. Ha körülnézünk a boltokban, akkor szinte csak külföldi árut látunk, külföldi tulajdonú üzletekben vásárolunk, a reklámok zöme külföldi árut hirdet, tíz végzett hallgatóból legalább nyolc külföldi cégnél dolgozik, legtöbbször az eladást elősegítő állásokban. A magyar lakosság a külföldről irányított nemzetközi marketing célközönsége, az alkalmazott marketingesek pedig zömében a külföldi cégek központjában megtervezett, elhatározott marketing végrehajtói, kivitelezói.

A nemzetközi marketing tehát a magyar piacon nagymértékben jelen van, a gond azonban az, hogy a termelést követő magasabb hozzáadott értékú fázisban megtermelt többlet - passzív szerepünknél fogva - szintén az aktív (azaz a külföldi) félnél csapódik le.

\section{Mi várható a jövőben?}

A kis kitérőnk után térjünk vissza a globális színtérre! A cikk elején felvázolt globális megatrendek egyikeként a világgazdaságban végbemenó radikális hatalmi átrendeződést jelöltük meg. Erre persze nemcsak 
mi jöttünk rá. Hadd hivatkozzak egy, a közelmúltban (2015. május 12-én) az USA-ban megjelent könyvre! A könyv címe: No Ordinary Disruption - The Four Global Forces Breaking All The Trends (magyarul talán: „Szokatlan zavarok - a négy globális eró, amely felülír minden trendet). A szerzők szerint a világ most olyan drámai átalakulásban van, amelynek magnitúdóját még csak megbecsülni sem tudjuk, amelynek mértéke a XIX. századi ipari forradalmat is meghaladja. A négy erő közül az első, az általunk is említett hatalmi átalakulás, azaz az, hogy a gazdasági tevékenység dinamizmusa, 'lókusza' a fejlődő országokba, illetve az ottani városokba vándorol, ahol a XIX. századi ipari forradalmat meghaladó mértékú fejlődés megy végbe. A gazdasági hatalom keletre és délre vándorol soha nem látott sebességgel. „Nem is olyan rég, 2000-ben a Fortune Global 500 nagyvállalat - a Shell, a Coca-Cola, az IBM, a Nestlé és az Airbus, hogy csak néhányat nevezzünk meg - 95\%-ának központja a fejlett országokban volt. 2025-re Kínában több nagyvállalat lesz, mit az USA-ban vagy Európában, és világ nagyvállalatainak (egymilliárd dollár éves forgalom felettiek) fele a fejlődő világból jön majd" (Dobbs et al., 2015, p. 5.).

Valóban a nemzetközi szervezetek elörejelzési is kivétel nélkül - radikális átalakulást vetítenek előre. Az átalakulás lényege, hogy az elkövetkező egy-két évtized alatt a világgazdaság és ebből következően a világpolitika is nagyon komoly hatalmi átalakuláson meg végbe. Az átalakulás lényeg az, hogy az eddigi fejlett régiók (USA, Európa, Japán) veszítenek jelentóségükból, és a Chindia (Kína, India), a BRICS (Brazília, Oroszország, India, Kína és Dél-Korea), vagy a CIVETS (Columbia, Indonézia, Vietnám, Egyiptom, Törökország és Dél-Afrika) országok jelentős előrehaladást mutatnak majd mind gazdasági, mind pénzügyi, mind politikai téren. Új, multipoláris világrend alakul ki, amely komoly változásokat igényel majd a vállalatok, és természetesen a marketing részéról is.

Mielőtt a változás marketingvonatkozásait vennénk górcső alá, tekintsük át ezen előrejelzések néhány fontos megállapítását!

\section{A gazdasági átrendeződés}

A fejlődő országok jellemzően magasabb éves növekedést produkáltak - még a válság alatt is - mint a fejlett országok. Az elórejelzések szerint ez a növekedési különbség a jövőben is megmarad, következésképpen részesedésük a világ GDP-termelésében egyre nagyobb lesz. Az NIC tanulmánya McKinsey Global Growth Modeljének négy forgatókönyvére hivatkozva, bemutatja, hogy a világ GDP-termelésében az USA, Európa és Japán 2010-ben meglévő közel 60\%-os aránya 2030ra 40-43\%-ra fog csökkeni, miközben Kína és India 2010-es 12\%-os részesedését közel meg fogja duplázni.
Ennek következtében a kínai GDP meg fogja haladni az USÁ-ét és kb. azonos lesz az Európában megtermelttel.

A szakma ezen országokat feltörekvő országoknak (emerging countries) nevezi. Két kutatóintézet is azonban azt javasolja, hogy ezen a megnevezésen már most változtassunk:

A ZenithOptimedia szerint az emerging markets kifejezés már most elavult, mert ezen országok közül néhány már olyannyira fejlődött, hogy sok tekintetben felveszi a versenyt a fejlett országokkal. Megalkották a „,rising markets” (szárnyaló piacok) kifejezést.

Az EY (Ernst and Young) kutatóintézet pedig kiadványában az „RGM - rapid-growth markets” (gyorsan növekvő piacok) kifejezést használja.

\section{A gyorsuló városiasodás}

A gazdasági növekedés egyik kulcstémája az urbanizáció. „A városok és városi térségek jelentősége egyre növekszik a globális gazdasági folyamatok és a nemzetállami politikák keretei között...” (Somlódyné, 2011, p. 28.). Európában és Észak-Amerikában az urbanizáció a XVIII. és a XIX. században ment végbe, Dél-Amerikában a XX. században. Ázsiában (Kínában és Indiában) most történik. Az elmúlt három évtizedben a városokban élők száma évente mintegy 65 millióval emelkedett (Dobbs et al., 2015, p. 18.), zömmel Kínában és Indiában. A városiasodás nemcsak egyszerú költözést jelent, hanem életforma-változást (hozzáférést az oktatáshoz, a kultúrához, álláslehetóséget stb.), amely egyidejúleg feltétele az iparosodásnak is.

Kínában a modernizáció kezdetekor népességnek, mintegy 20\%-a élt városokban, 2010-re arányuk megközelítette az 50 százalékot, ami hozzájárult az ország rohamos fejlődéséhez, de egyidejúleg a társadalmi feszültségek (jövedelemkülönbségek) kiéleződéséhez is (Székely - Dobi, 2014). A városi lakosság globális alakulását a 4. ábra mutatja be.

\section{A városi lakosság arányának előrejelzése 2030-ig (\%) \\ Percent urban population}

80

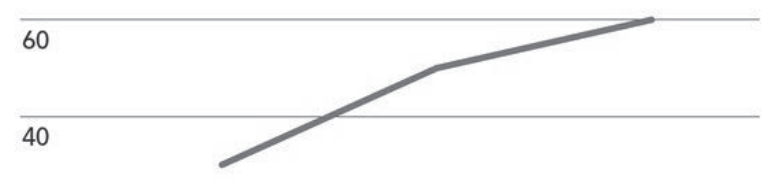

20

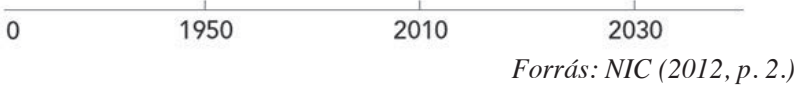


A gazdasági fejlődés eredményezi a városiasodást, a városiasodás ugyanakkor gyorsítja a gazdasági fejlódést. Emberek tömegei válnak a városban fogyasztókká és lépnek be a középosztályba. Dobbs és társai szerint 2025-re a világ 200 legnagyobb városának egynegyede Kínában lesz, és addig a világon mintegy hárommilliárd, korábban nem fogyasztó szegényből lesz vásárló és így a (nemzetközi) marketing célközönsége.

\section{Növekvő középosztályok, növekvő fogyasztás}

A gazdagodás a fejlődő világban (elsôsorban Ázsiában) tehát a középosztályok kialakulását és komoly erôsödését fogja magával hozni. Minden elörejelzés egyetért ebben a fejleményben:

- Az NIC 2012-ben készített előrejelzésének legkonzervatívabb modellje szerint is a jelenlegi egymilliárdos középosztály legalább kétmilliárdra emelkedik. Mások szerint ez a szám 2030-re hárommilliárd lesz. Leginkább Ázsiában és ezen belül is Indiával az élen, amely kissé meg fogja előzni Kínát. És ez természetesen a fogyasztás megoszlásában is radikális változást fog eredményezni (5. ábra).

5. ábra

A középosztályok fogyasztásának alakulása 2010 és 2030 között (Az NIC, 2012 adataiból számítva)

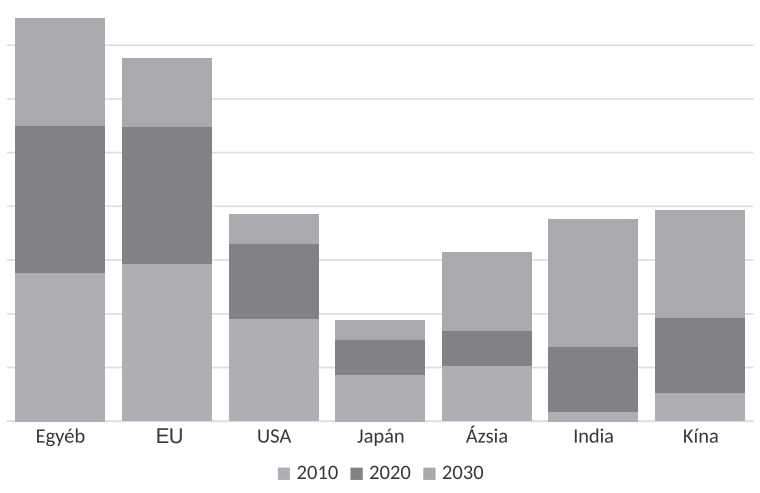

- Kharas és Gertz (2010, p. 5.) hasonló eredményre jutottak kutatásaikkal: az ő szcenáriójuk szerint 2030-ra a világ lakosságának kétharmada, mintegy ötmilliárd ember tartozhat a középosztályba.

- Az EY szerint a gyorsan növekvő országokban már 2022-re nagyobb lesz az évi 35 ezer dollár jövedelemmel rendelkező háztartások száma, mint az USA-ban. Ezek számát ma Kínában 80 millióra, Brazíliában és Oroszországban 15-15 millióra, Indiában, Mexikóban és Törökországban egyenként 10-10 millióra teszik.
- De hasonló következetésre jut a ZenithOptimedia is. Szerintük 2025-re a szárnyaló országok fogyasztása eléri az évi 30 trillió dollárt, a világfogyasztás $50 \%$-át. Ez a kapitalizmus eddigi történetének „legnagyobb lehetösége" - írja a ZenithOptimedia elemzője McKinsey elemzésekre hivatkozva.

\section{A nemzetközi marketing jelentőségének növekedése}

Ha minden az elôrejelzések szerint alakul, a fejlődést váratlan fejlemények nem állítják meg, akkor ez a hatalmas fogyasztásnövekedés a nemzetközi marketing hasonló mértékü fejlődését is fogja jelenteni.

Az új piacokból minden nyugati vállalat - legyen az akár nagyvállalat vagy éppen KKV - ki akarja majd szakítani a maga részét. Ez azonban nem lesz egyszerú. Ez a növekedés a világ azon részén következik be, amely csaknem minden vonatkozásában más, mint a nyugati világ. Nagy az üzleti távolság, és egészen más a kultúra. Ezek ismerete nélkül nehéz üzletet kötni, sikeres marketinget folytatni.

Mindebból az következik, hogy a nyugati világban a nemzetközi marketing a jövóben egyre nagyobb jelentôségre tesz szert és tartalma, az alkalmazott módszerei komoly változáson mennek majd át. E változások bemutatása külön tanulmányt igényelne, egy azonban biztos: kiemelkedóen fontossá válik majd a nemzetközi marketingnek a kulturális környezet megismerésére vonatkozó tanítása.

A célpiaci vevók viselkedésének, igényeinek, vásárlói magatartásának ismerete a marketingmix minden eleménél fontos, és a szóban lévő országok (fő́leg Kína és India) esetében minden elemére nagy hatással van. Ifj. Rekettye (2016) a marketingkommunikáció jövőbeni alakulásával foglalkozó kutatása egyértelmúen bizonyította a marketing alakulásárára vonatkozó indiai és az európai várakozások közötti különbséget, és azt is, hogy India pl. sokkal lokalizáltabb marketingkommunikációs megközelítést igényel majd.

Azért, hogy az ezekre a piacokra belépó vállalatok megvethessék lábukat a piacon, nemcsak a felső tízezernek, de a középosztálynak is elérhetố árú, az igényeiknek megfeleló termékeket és szolgáltatásokat, olyan olcsóbb technológiát és üzleti modelleket kell kínálniuk, olyan marketingkommunikációs mixet kell alkalmazniuk, amelyeket a helyi kultúrához adaptálnak. A lokális jelenlét (kutatás, fejlesztés, marketing) fontos lesz a várhatóan gyorsan változó fogyasztói igények kielégítésében.

\section{Felhasznált irodalom}

Baldwin, R. E. (2011): Trade and Industrialisation After Globalisation's Second Unbundling: How Buil- 
ding and Joining a Supply Chain Are Different and Why It Matters. in: Feenstra, R. C. - Taylor, A. M. (eds): Globalization in an Age of Crisis: Multilateral Economic Cooperation in the Twenty-First Century. Cambridge, MA: National Bureau of Economic Research

Baldwin, R. - Ito, T. - Sato, H. (2014): The smile curve: Evolving sources of value added in manufacturing. Working paper (http://www.uniba.it/ricerca/dipartimenti/dse/e.g.i/egi2014-papers/ito, letöltve 2015. június 22.)

Czakó E. - Reszegi L. (2010): Nemzetközi vállalatgazdaságtan. Budapest: Alinea Kiadó

Czinkota, M.R. - Ronkainen, I. A. (2004): International Marketing: A Global Perspective. Upper Saddle River, NJ: Addison-Wesley Publishing Company

Dobbs, R. - Manyika, J. - Woetzel, J. (2015): No Ordinary Disruption - The Four Global Forces Breaking All The Trends. New York: PublicAffairs

EY (2014): Rapid-growthmarkets, EY Rapid-Growth Markets Forecast 2014 February. Published in Cooperation with Oxford Economics

Hetesi E. (2009): A válság marketingje - a marketing válsága?: a 21.század marketingkihívásai - lesznek-e válaszok? Jelenkori társadalmi és gazdasági folyamatok, 3-4: p. 81-93.

Kharas, H. - Gertz, G. (2010): The New Global Middle Class: A Cross-Over from West to East. in: Li, Ch. (ed): China's Emerging Middle Class: Beyond Economic Transformation. Washington, DC: Brookings Institution Press

Keegan, W. J. - Green, M. C. (2013): Global Marketing. Upper Saddle River NJ: Pearson Prentice Hall

Mühlbacher, H. - Dahringer, L. - Leihs, H. (2006): International Marketing. London: International Thompson Business Press

NIC (National Intelligence Council) (2012): Global Trends 2030: Alternative Worlds, NIC 2012-001, (www.dni.gov/nic/globaltrends, letöltve 2015. június 24.)

Rekettye G. - Hetesi E. (2010): Responsibility for the Future of the World - Paradigm Shift in the Theory and Practice of Marketing. in: J. L. P. Galán (ed.): Pecunia: Revista de la Facultad de Ciencias Económicas y Empresariales: p. 177-189.
Rekettye G. - ifj. Rekettye G. (2009): A világjövője - a jövő marketingje. Vezetéstudomány, XXXX. Evf. 2. szám: p. 2-9.

Rekettye G. ifj. (2016): A következó évtized marketingkommunikációja - egy nemzetközi kutatás eredményei. Vezetéstudomány, 3. sz.: p. 12-22.

Rekettye G. - Tóth T. - Malota E. (2015): Nemzetközi marketing. Budapest: Akadémiai Kiadó

Rekettye, G. - Rekettye, G. Jr. (2013): Global Trends and Their Influence on Future Business Performance. International Journal of Business Performance Management (IJBPM), 14(1): p. 95-110.

Somlyódyné Pfeil E. (2011): Az agglomerációk jelentőségének változása az államszervezés és a városi kormányzás szempontjából. Tér és Társadalom, 25. évf., 3. szám: p. 27-59.

Székely-Doby A, (2014): Urbanizációs tendenciák és a vidék-város ellentét gyökerei Kínában. Köz-Gazdaság, 2014/3: p. 84-98.

Unesco World Report (2009): Investing in Cultural Diversity and Intercultural Dialogue. Paris: Published in 2009 by the United Nations Educational, Cultural and Scientific Organization

United Nations Conference on Trade And Development (2013): Global Value Chains and Development - Investment and Value Added Trade in the Global Economy. Geneva: UNCTAD

United Nations Conference on Trade And Development (2014): World Investment Report 2014. New York; Geneva: United Nations

UNCTAD (2015): World Investment Report. New York; Geneva: United Nations

World Bank (2011): Global Development Horizons 2011, Multipolarity: The New Global Economy, The International Bank for Reconstruction and Development. Washington, DC: The World Bank

World Trade Organization (2013): International Trade Statistics, 2013. Geneva: WTO

World Trade Organization (2014): World Trade Report 2014 - Trade and development: recent trends and the role of the WTO. (Website: www.wto.org)

Zenithoptimedia (2014): 2038: Six Trends For The Next 25 Years, The Roi Agency, http://www.zenithoptimedia.com/wp-content/uploads/2014/01/ ZO2038TrendsReport.pdf (letöltve: 2015. július 21.) 